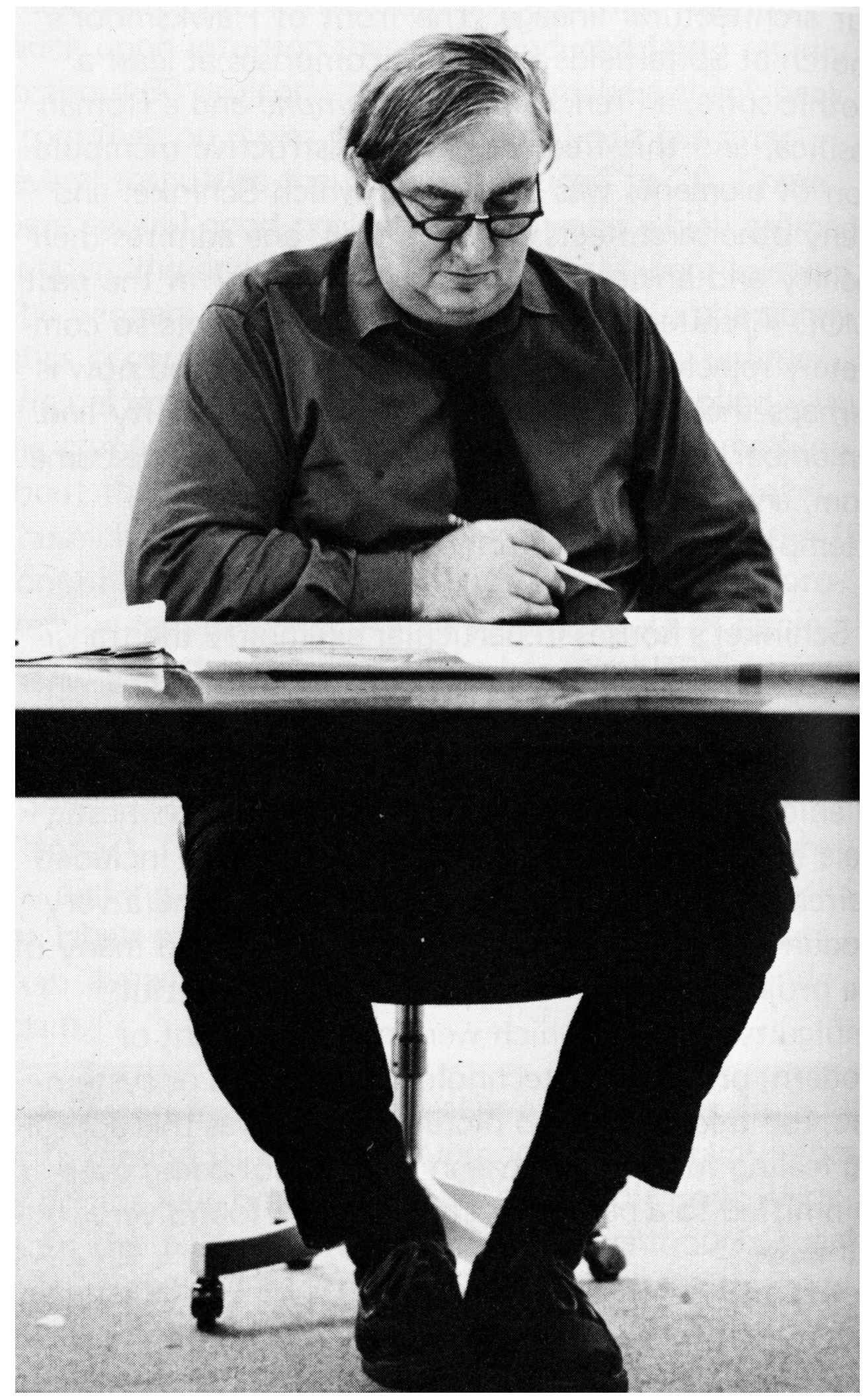




\section{Multiple Authorship: The Collaborative Production of Knowledge in the Shinkenchiku Residential Design Competition (1965-2020) Cathelijne Nuijsink}

This paper challenges the notion of the heroic genius as driver of invention and development in architectural culture. It considers the production of architectural ideas prior to design as an integral part of the production of architectural projects and takes the Shinkenchiku Residential Design Competition (1965-2020), a yearly housing ideas competition from Japan, as a tangible case study for exploring notions of multiple authorship. The paper focuses on the editions of the competition judged by Toyo Ito, Rem Koolhaas, and Kazuyo Sejima-who respectively set the provocative themes of "Comfort in the Metropolis" (1988), "House with No Style" (1992), and "The Possibilities of NonMovement" (1996)-to illustrate how this ideas competition functions as a fruitful dialogue between judge and contestants that produces architectural knowledge collaboratively. At the same time, by de-mystifying the genius of the single "star architect" judge, this paper aims to contribute to the ongoing quest to write a more inclusive global history of architecture that reveals voices hitherto silenced.

\section{KEYWORDS}

Multiple Authorship, Shinkenchiku Residential Design Competition, Discussion Platform, Multicultural Responses, Collaborative Production of Knowledge

\section{PALABRAS CLAVE}

Autoría múltiple, Shinkenchiku Residential Design Competition, foro de discusión, respuestas multiculturales, producción colaborativa de conocimiento

\section{The Japanese publishing house Shinkenchiku-sha} launched an international housing ideas competition in 1965, in an attempt to rejuvenate their long-running architecture magazine Shinkenchiku (New Architecture, 1925-). Following an editorial dispute, Shinkenchiku magazine had become a fairly conservative magazine, with the editors wary of any controversial opinions.' To enliven the magazine and attract young readers, the editorial board decided that the journal needed some avant-garde pages. Inspired by a series of housing ideas competitions that the magazine had featured just after the Second World War, they decided to launch a new ideas competition. The Shinkenchiku Residential Design Competition

\section{Cathelijne Nuijsink}

is a Lecturer and Postdoctoral Researcher at the Institute for the History and Theory of Architecture (gta) at the ETH Zurich. She obtained Master's in Architecture degrees from TU Delft and The University of Tokyo (Japan) and a Ph.D. in East Asian Languages and Civilizations from the University of Pennsylvania. Her current research focuses on cross-cultural knowledge exchange in architectural culture and aims to contribute to a more dynamic and inclusive history of architecture, using the Shinkenchiku Residential Design Competition (1965-present) as a case study. She is currently working on the book manuscript Another Historiography: The Shinkenchiku Residential Design Competition, 1965-2020 (Jap Sam Books, 2022), which will be accompanied by the traveling exhibition Call for Lost Entries: The Shinkenchiku Residential Design Competition, 1965-2020 and a website that brings together these lost entries.

E-Mail: cathelijne.nuijsink@gta.arch.ethz.ch ORCID iD: 0000-0001-8900-6529
Fig. 01

The authorized image of James Stirling judging the Shinkenchiku Residential Design Competition of 1979, titled "A House for Karl Friedrich Schinkel," is undermined when one considers the multicultural responses and their contribution to the larger discussion that were facilitated by the brief. Credits: The Japan Architect (February 1980), p. 52. 
(1965-2020), as it was named, differed from other Japanese competitions because it was international from the outset. Both the announcement of the competition and the winning entries were published bilingually; in Japanese in Shinkenchiku and in English in its sister-magazine The Japan Architect. Besides being an exceptionally long-running competition (the competition has seen forty-eight editions since 1965, with future competitions planned), what sets this ideas competition apart from others is that it is judged by one architect. Since being launched in 1965, many well-known international architects have served as judges, from Richard Meier (1976), Peter Cook (1977), James Stirling (1979) (fig. 01), Bernard Tschumi (1989), Rem Koolhaas (1992), Jacques Herzog (1997), and Winny Maas (2001), to some of Japan's most respected architects -Kiyoshi Seike (1965), Kenzo Tange (1966), Kazuo Shinohara (1972), Arata Isozaki (1975), Tadao Ando (1985, 1991), Toyo Ito (1988, 2000), Kengo Kuma (2006), and Kazuyo Sejima (1996). Unlike the "mediated" briefs that result when a team of organizers or jury members jointly decide on one theme, the Shinkenchiku competition allows the single judge to freely choose a competition theme, thereby consciously and even provocatively stirring up international architectural debate.

COLLABORATIVE PRODUCTION OF KNOWLEDGE
The intrinsic competition logic is crucial to understanding the competition as a cross-cultural platform for knowledge exchange. To begin, the judge decides on a competition theme against the backdrop of ongoing international debates, which thus enables the judge to craft an independent position within existing architectural dialogues. Once the judge has independently chosen the competition theme and it has been announced, entries are received from around the world. These entries function as different cultural responses to the judge's theme, and illustrate diverse formulations of the shared design problem. These responses, in turn, help shape the judge's concluding remarks. Since the possible responses to the theme vary to a great extent, judges commonly use their final remarks as an opportunity to refine the original argument as set out in the competition brief. Finally, the publication of the judge's final remarks as well as a large selection of winning designs in both Shinkenchiku and The Japan Architect bounce off in different directions and cause a series of "aftereffects." At every step in this competition, local and foreign ideas of house and home inform and inspire one other.

The selection of a single "master" architect as judge and jury -a component particular to this competition- suggests the grand narrative of a heroic architect claiming sole authorship. This paper, however, argues just the opposite. While renowned architects as adjudicators have certainly helped the competition succeed, what makes this competition worthwhile as an object of study, I argue, is the cultural diversity of the entries, and the resultant dialogue between the respective judge and the contestants that plays out on the pages of Shinkenchiku and The Japan Architect. As such, this paper posits that we should regard the plurality of the multicultural responses as a valuable contribution to the larger discussion formally initiated by the judge. Studying the contestants' entries and examining how they interact with the competition theme enables us to highlight voices in the debate that were hitherto muted. To elucidate the competition logic and how it has resulted in a fruitful dialogue between judge and contestants' producing architectural knowledge 
collectively, this paper examines three such discussions between the judge and the contestants. For space reasons, it is not possible here to depict the full spectrum of these discussions, such as the resonance of the competition in the local media, the impact of this competition on the careers of the individual contestants, or the lost entries. ${ }^{2}$ The paper will, however, reveal how the competition logic intrinsic to the Shinkenchiku Residential Design Competition is not merely propelled by the autonomy of the single judge, but that the multiple cultural responses from the contestants make an equal contribution to knowledge production.

TOYO ITO'S "COMFORT IN THE METROPOLIS" OF 1988
When Toyo Ito served as the judge of the 1988 edition of the Shinkenchiku Residential Design Competition, the architect had already been running his own architectural firm for seventeen years. What started in the 1970 s as a critique of the domination of technology in the urban environ-

ment shifted in the 1980s to an interest in Tokyo's dynamic, yet incoherent city fabric. ${ }^{3}$ Influenced by the rapid development of electronic technologies and media at the height of an era of strong economic growth in Japan, Ito -in his competition brief "Comfort in the Metropolis"- set out to comment on the way consumer lifestyles have made the private house in urban Japan a superficial phenomenon. In the competition brief, he went on to describe how the new urban environment also demanded a new type of housing:

\footnotetext{
"Our daily lives in the metropolis are repeated round trips between barrack-like houses and glittering, dreamlike illusionary space, which although unprecedented and wonderful, seem to be working a fundamental change in our perception of pleasure and relaxation. We have not, however developed a kind of house that is pleasant and relaxing in ways suited to this extremely technological environment."
}

To resolve this impasse, Ito called on contestants "to plot a new environment for the body," with a design liberated from existing social frameworks. ${ }^{5}$ Referring to his own project Pao Dwelling for the Tokyo Nomad Girl (1985), a lightweight, nomadic dwelling that allowed its (female) inhabitant to enjoy a vibrant urban lifestyle, Ito suggested that a new concept of a house could be a space enclosed merely by thin and formless membranes. At the same time, he encouraged the contestants to use these new technologies in their own ways so that they would contribute directly to their own pleasure and comfort while creating a dwelling that, from within, would make the technological environment outside appear brighter and more welcoming.

Ito's announcement for the Shinkenchiku competition of 1988 attracted 373 entries ( 247 from Japan and 126 from overseas), which can be regarded as 373 cultural responses to Ito's competition brief. Ito selected two first prize entries, two second prizes, four third prizes entries, and eleven honorable mentions, with all the prize-winning entries featured in The Japan Architect and Shinkenchiku, and thus included directly in the discussion. One first prize went to the AA School of Architecture tutor Peter Wilson, who designed an illusionary space in the form of a jellyfish-like electronic shadow as a parasite on judge Toyo Ito's own Tower of Winds (1986) project in Yokohama. To Ito, Wilson's proposal suggested a new kind of architecture that responded well to consumer society. Here, comfort was defined 
La Caja Oscura De La Tecnopolis;

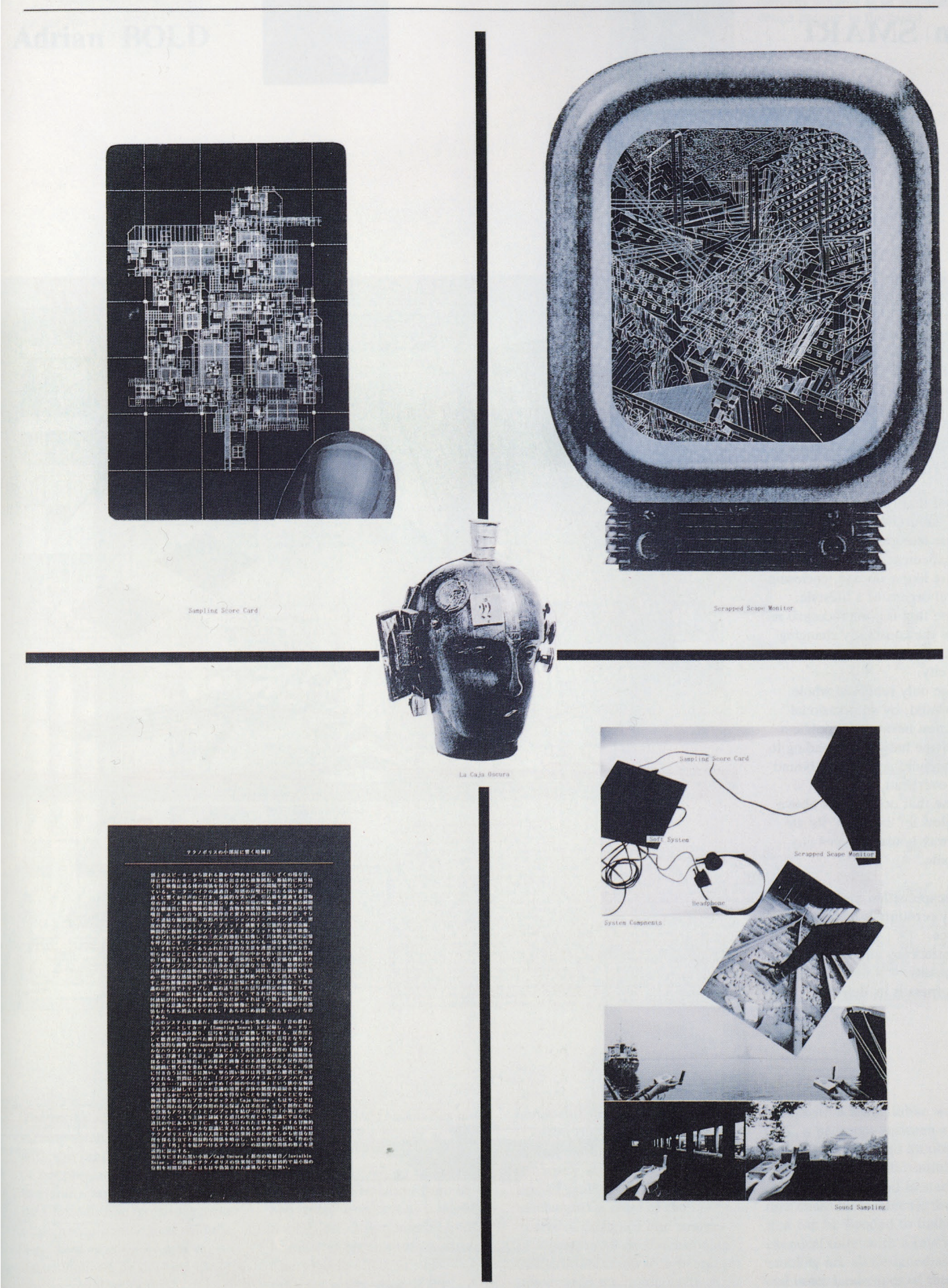


as a respite, a zone of minimal electronic interference $(m u)$ in the shadow of Ito's own constantly changing Tower of Winds. The other first prize went to Toshikazu Ishida and Diana Juranovic's quite different kind of "Comfort in the Metropolis." Ishida and Juranovic designed a house as a black box (caja obscura) in which to collect urban sounds that, when reproduced, could help visualize scenes (fig. 02). The process of going from sound to something visual, Ito responded in the judge's comments, is an architectural act that in itself casts a critical eye on contemporary architecture and the myth of originality. Adrian Bold secured a second prize for his rejection of discomfort. His house resembles a Roman villa, in which architectural elements such as a "fountain," "refrigerator," "fireplace," "toilet," and "bath" mimic the urban jungle and allow for more acute cultural experiences. Perhaps the most optimistic response to consumer society came from Azby Brown, whose tent-like "Installation for Urban Living" (fig. 03), made of whatever

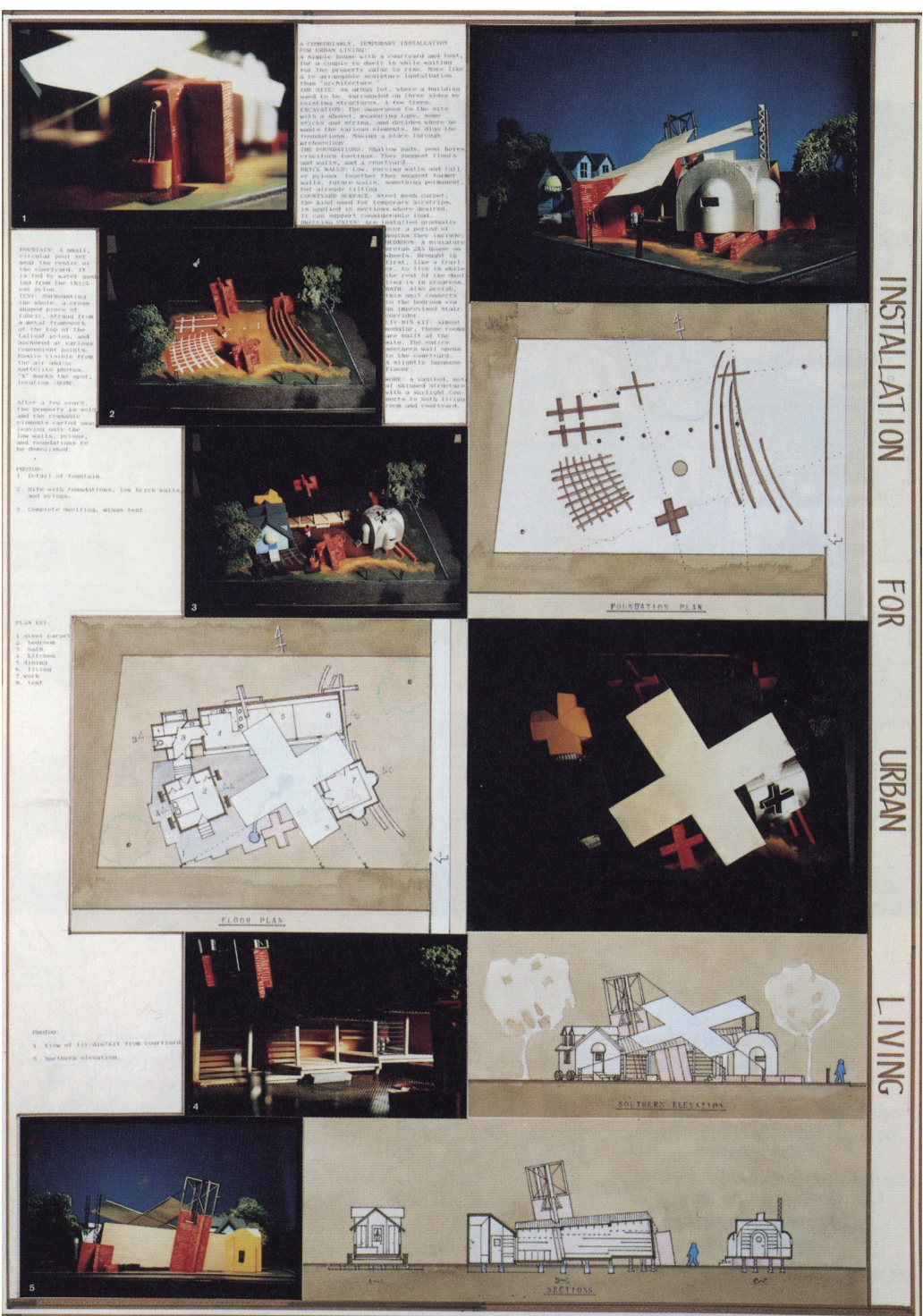

Fig. 02

Toshikazu Ishida and Diana Juranović cast a critical eye on contemporary architecture and the myth of originality with a black box in which to collect urban sounds that, when reproduced, bring visual scenes to mind. First prize in the Shinkenchiku Residential Design Competition of 1988. Credits: Toshikazu Ishida and Diana Juranović, The Japan Architect (March 1989), p. 11.

Fig. 03

Azby Brown finds urban comfort in a makeshift home. Third prize in the Shinkenchiku Residential Design Competition of 1988. Credits: Azby Brown; The Japan Architect (March 1989), p. 15. 
Fig. 04

Jos Roodbol's drawing expresses the idea that a comfortable home in the metropolis is no more than an ephemeral dream. Honorable mention in the Shinkenchiku Residential Design Competition of 1988. Credits: Jos Roodbol, The Japan Architect (March 1989), p. 27.

materials were on hand, suggested an architecture capable of breaking through consumer society. Other responses included, for example, a temporary, movable stage suspended from a high-wire frame that responds to the artificial nature of the city (Ben Smart), a parasitic shell hanging behind a billboard, from where the urbanite enjoys gazing over the city in secret (John Hampton), a tower-like house clearly divided into intellectually, physically, and psychologically comfortable spaces paradoxical to the confusion in real urban spaces (Guillermo Muller), and a suggestion that a comfortable home in the metropolis is ephemeral, little more than a dream (Jos Roodbol) (fig. 04). While many responses were clearly inspired by Ito's own reference to a transient quality of dwellings, the profusion of entries and the diversity among the winning submissions that were subsequently published already suggest that Ito used the competition to further stake out his own interests, and to test, among fellow architects, his ideas regarding the influence of consumer society on architecture.

REM KOOLHAAS'S "HOUSE WITH NO STYLE" (1992)

In 1992, Koolhaas revived a two-century-old discussion on "style" within the framework of the Shinkenchiku competition with a provocative competition brief title: "House with No Style." In a symposium in 1990 -marking his departure as a professor from the Delft University of Technology- Koolhaas had already openly expressed his unease with the issue of style. In a book release accompanying the symposium, he complained that Dutch architects in the 1990s were still using references to functionalism, which Koolhaas thought was "an act of despair" and "a spasmodic relapse into a past heroic moment." $\mathrm{His}$ "House with No Style" competition brief was one of the shortest and most cryptic in the history of the Shinkenchiku Residential Design Competition, yet it effectively aligned with Koolhaas's habit of undermining architectural conventions and his concept of "anti-architecture." The brief

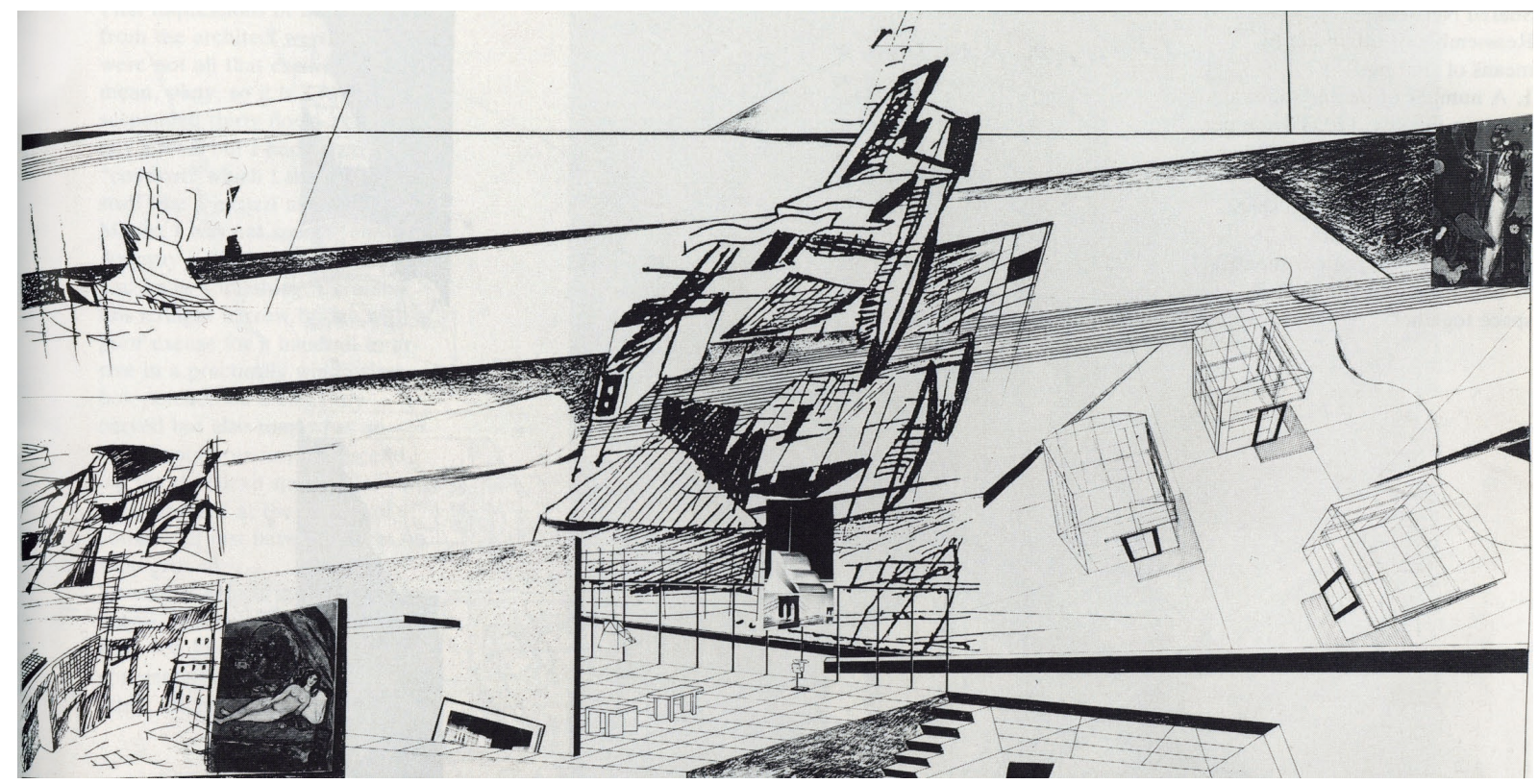


called on contestants to come up with methods for shedding style and stopping the automatism of simple form-making for its own sake. A "house with no style," Koolhaas wrote in the brief, should be a house that "avoids recent clichés and nostalgia," contains a program "purged of the frivolous and the decorative," and is appropriate to a "'designer-free' zone."

After reviewing 732 competition entries (306 from Japan and 426 from thirty other countries), Koolhaas selected sixteen winning designs; one first prize, one second prize, one third prize, and thirteen honorable mentions. First prize went to Yosuke Fujiki, who responded with a catalogue of houses containing one hundred defective houses "that help us make original lifestyles." Fujiki believed that the challenges of a house without gas and water pipes or a roof would help do away with fixed ideas about housing. For Koolhaas, the systematic suppression of elements in this entry "triggers uselessness, recharges what we have," and at the same time "destabilizes the notion of a house in an absolute anti-aesthetic way."

Second prize winners Mitsugo Okagawa and Yutaka Kinjo used the competition brief as the basis for exploring another kind of modern architecture through bending Ludwig Mies van der Rohe's "universal space" into a "house with no style" for AIDS patients living in a delirious Tokyo. Koolhaas lauded the second prize winners' courageous move of introducing a disease, AIDS, into an otherwise sanitized profession. "To mix architecture with AIDS forces people to think about the destiny of human beings," stated Koolhaas. ${ }^{9}$ Another response to Koolhaas's "House with No Style" was an entry from an unidentified designer reporting from the Bosnian War. The third prize was awarded not based on the project itself, but on its anonymous authorship; according to Koolhaas in his final comments as judge, its anonymity effectively demonstrated a critique of the whole system of architectural competitions. Paulo Sanguinetti Rivas and Bane Gaiser, to name yet another interpretation of "House with No Style," were captivated by the idea of a "designer free zone" and designed a tower-house in which the occupants themselves -using moveable pieces of furniture-can decide how they want to live. Akira Imafuji designed a house for a blind person, in which narrow, 1.15-meter-wide corridors provide the inhabitant freedom of movement, rather than limiting how they live. As a result of being able to touch the walls on both sides while moving through this house, the inhabitant will feel free and comfortable, according to Imafuji. ${ }^{10}$ Kevin Woods and Charlotte Sheridan, another duo of contributors to the "style" discussion, argued that in order to come up with a house with no style, the architect's mind first must be freed from any historical references or preconceptions. They reduced the design process to a mathematical formula, which results in a pattern of living freed from conscious and unconscious influences of style." Joanne Mackenzie and Garth Davies focused on the innate responses of individuals to a personally chosen object. With a collage of bodies -from which the faces have been cut out- holding an object, the authors evoked a universal response beyond style. ${ }^{12}$

Although Koolhaas, in his remarks, was critical of the many references that still harked back to form, style, and aesthetics, he did point to a few remarkable entries that revealed serious research on how to shed style. ${ }^{13}$ Fujiki's first prize entry exceeded even Koolhaas's expectations from the competition, indicating that this architect had an even better understanding of the theme of "no style" than Koolhaas 


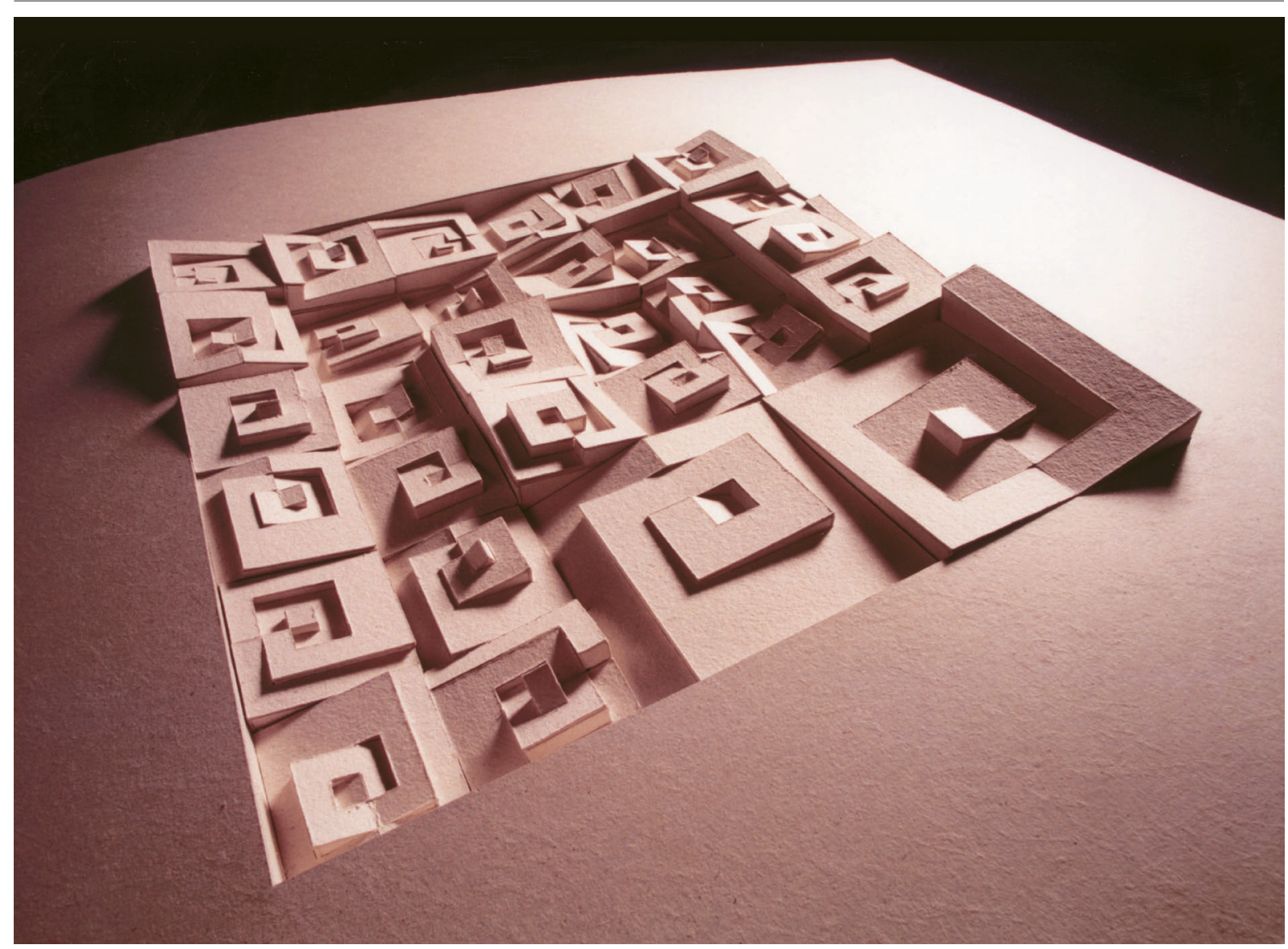


himself. Beyond the opportunity to position himself as a theorist within global debates, the competition of 1992 also served a second purpose for Koolhaas. For him, the act of serving as judge created a space for architectural thinking (as opposed to building) in which to "collectively" develop ingenuity and propel architectural knowledge forward.

\section{KAZUYO}

SEJIMA'S "THE

POSSIBILITIES OF NON-MOVEMENT" (1996)
Sejima's 1996 edition of the competition, "The Possibilities of Non-Movement," coincided with the emergence of digital architecture and the exploration of architecture beyond cubic volumes. Aware of the highly globalized environment "in which everything has become informationalized, speed has become increasingly faster, and various forms of interchange have become possible," she called attention to the fact that, although the surroundings are moving faster, architecture does not move at all. ${ }^{14}$ While architecture's static aspect might at first be seen as a hindrance to this movement, Sejima recognized opportunities for design in the tension between architecture's static aspect and a rapidly changing society. She thus formulated her competition brief in a way that encouraged contestants to go beyond a solution that merely reflects either movement or non-movement. By juxtaposing the static with the dynamic, she saw opportunities for this non-moving aspect to expand the horizons of architecture, rather than being viewed as a limitation.

From the 439 competition entries (272 from Japan and 167 from abroad), Sejima selected twelve winning designs; one first prize, six other prizes, and five honorable mentions. In her comments as judge, Sejima elucidated three general approaches to the subject matter of "The Possibilities of Non-Movement." The first approach came from contestants who established a dialogue between things that move and things that do not move. Their entries contrast the non-moving building with moving appliances (moveable screens and partitions, curtains, furniture) to suggest an architecture of change. A second approach embedded in the proposals involved layering the virtual space of media and computer "cyber space" over non-moving constructions, and in doing so contrasting "things that move" with "things that don't move." A third approach was rooted in proposals that introduced a non-concrete system, such as an urban or media network, to suggest an urban lifestyle, a house diagram, or the like. ${ }^{15}$

Vinko Penezić and Krešimir Rogina's entry (fig. 05) is an attempt to recreate both the static quality of nature as well as the constantly changing diversity within it through architecture. They grasped the theme as suggesting that, in nature, "everything is on the move but still appears as a very stable and infinite system."16 By likening natural processes to digital processes that evolve exponentially rather than mechanically, they started their entry by drawing spirals as a planar pulsation that ended up as a geometric structure fractured into a thousand pieces. The resulting "architecture of emergence and disappearance" follows these natural processes in a precise way. ${ }^{17}$ Penezić and Rogina thus added the idea of "technological disappearance" to the discourse in an era when technologies were regarded as something that should be visible. Pornchai Boonsom and Jarrod Broussard contributed to the discussion with the idea that "nothing in motion can be understood without static reference points." ${ }^{18}$ They illustrated their idea with a city map exploring the tension between movement and non-movement. In the first
Fig. 05

Vinko Penezić and Krešimir Rogina took up the theme of nature to highlight that everything is on the move but still appears as a very stable and infinite system. Second place in the Shinkenchiku Residential Design Competition of 1996. Credits: Vinko Penezić and Krešimir Rogina. The Japan Architect (Winter 1996 IV), pp. 228-29. 


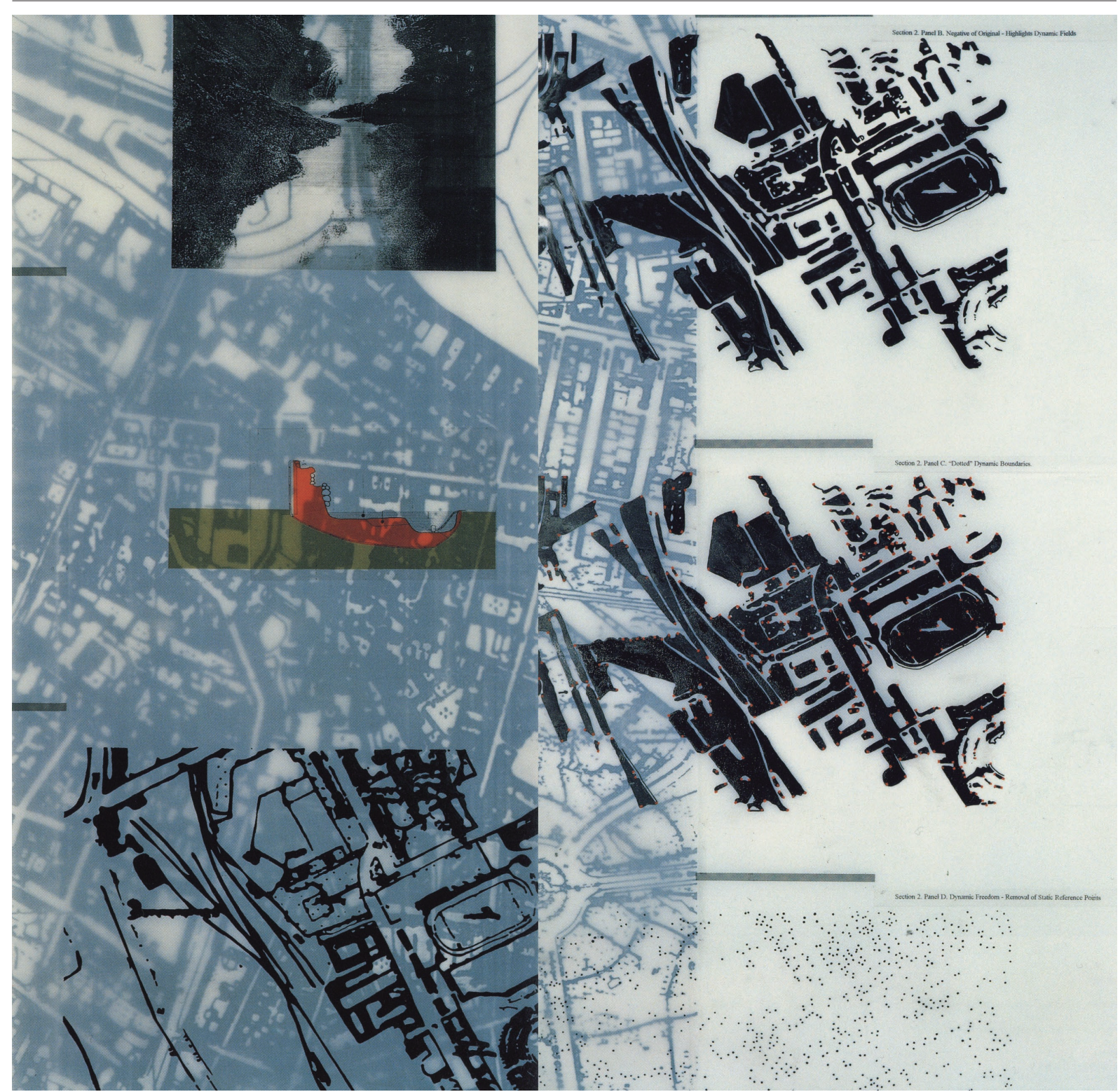


panel, the buildings, in black, represent static reference points, while the white open spaces signify fields of dynamic systems (fig. 06, left). In the second panel, they reversed the colors to highlight the tension between open spaces in motion and their respective static borders. With the nowblack areas defined as being in motion, the now-white areas are conceptualized as the channeling forces that contain and define motion (fig. 06, right). The aspect of this submission that struck Sejima as being particularly stimulating was that it contained an abstract quality of thinking in its formalization of the distinction between non-movement and movement. Jurgen Mayer's entry explored the tension between non-movement and movement based on the idea that the house is a space that binds you to a place, while the conditions around you make your imagination move. Jean-Philippe Lanoire responded with an interactive interface that makes the building not merely a container of information, but one that can turn information into architectural material. Shahed Saleem and Stefan White contributed to the discussion with the idea that the architecture of airport terminals gives an illusion of stability, but is, in reality, merely a fluid place where people pass through. First prize ultimately went to a proposal that relies on the concept of "when everything moves at the same speed, movement is rendered invisible." Using a series of time-lapse photographs with multiple exposures, contestants Richard Scott, Kirsten Whittle, and Jeremy Weate tried to find a way to visualize the flow of the movement, and thus actualize their theory. The resulting image displays a "phase space," an environment that responds directly to its users (fig 07). For Sejima, the striking aspect of this project lies in its ability to put forward the conditions for realizing a diagram of the dialectic between non-movement and movement.

Sejima's dialectical competition brief, in which she recognized design opportunities in the tension between architecture's static aspect and a rapidly changing society, resulted in a lively discussion about the possibilities that are inherent between movement and nonmovement. This collaborative brainstorming about possible answers to the design problem, in turn, helped Sejima position herself as an architect willing to go beyond simply bringing together the curvilinearity and digital architecture experiments so typical of the mid-1990s.

CONCLUSION

Histories of modern architecture still focus too often on heroic geniuses as drivers of invention and development in architectural culture. However, if we want a more global perspective on the history of architecture, we should raise awareness of the negotiated character of architectural production, recognizing that design is often propelled by multiple architects or emerges from the complex interplay between various actors from different national and professional geographies. This paper attempts to demonstrate that, despite a "master" architect serving as the single judge, the Shinkenchiku Residential Design Competition has operated as a platform for discussion in which judges and contestants (and readers) have crafted a space to "collectively" produce architectural knowledge. It is the logic intrinsic to this competition that gives rise to this discussion. For Toyo Ito, in 1988, the discussion was based on the belief that contemporary consumer society had created new urban lifestyles that, in turn, demanded a new kind of
Fig. 06

In Pornchai Boonsom and Jarrod Broussard's city map, movement and non-movement are rendered interdependently: buildings in black represent static reference points while the white open spaces signify fields of dynamic systems (left), and vice versa (right). Second place in the Shinkenchiku Residential Design Competition of 1996. Credits: Pornchai Boonsom and Jarrod Broussard, The Japan Architect (Winter 1996, IV), pp. 236-37. 


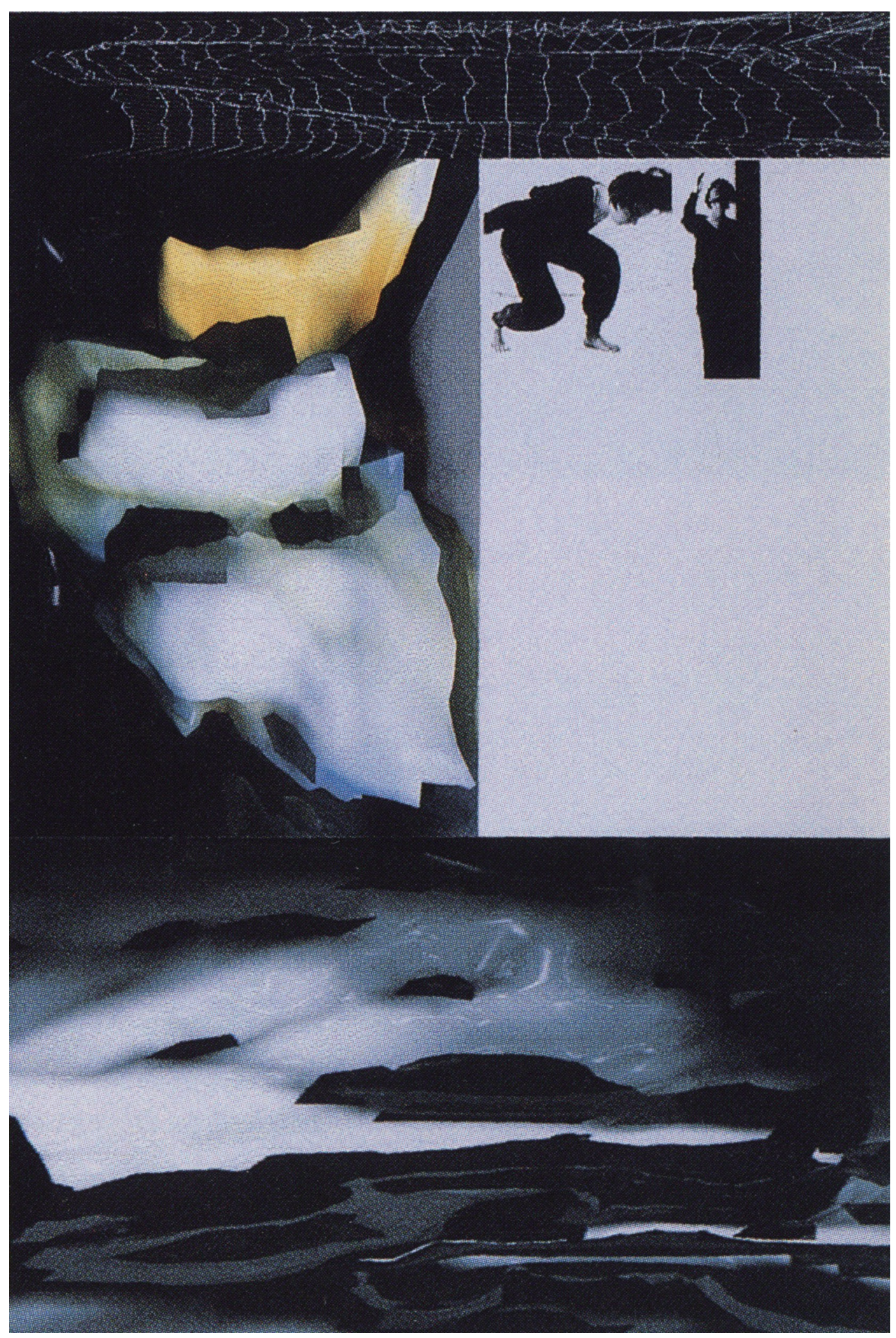


ephemeral dwelling. Despite the concrete image he provided in the form of his own then-recent design for Pao Dwelling for the Tokyo Nomad Girl, contestants submitted proposals that went as far as to translate "Comfort in the Metropolis" into a Roman villa or with the aid of sound boxes. Judging the 1992 competition served Rem Koolhaas particularly well as a moment of theoretical reflection at a time when he had begun involving himself in actual building projects. Much like the think tank AMO, which he set up in 1999, the framework of the competition allowed Koolhaas to explore a theme crucial to him in collaboration with others. The movement brought about by new media inspired Sejima, in 1996, to directly juxtapose such movement with the static aspects of architecture. For her, the competition was also not about finding one right answer, but rather about ideating with the contestants about all the directions that architecture could possibly move toward.

This article has thus striven to raise awareness about the asymmetries of power that are still present in our histories of architecture, which single-handedly credit "heroic genius architects." By studying the relations between the wide range responses to the competition brief created by a single judge in the Shinkenchiku competition, this article shifts attention to the valuable contribution of the "minor" voices of young architects, without whom the judge could never have propelled the debate in the same directions. To draw out this collaborative knowledge production and exchange of ideas, we have to engage with the inherent asymmetry at play in this competition, to expose these power relations, and to find methods to give a much stronger voice to responses from the "margins." RA
Fig. 07

Richard Scott, Kirsten Whittle, and Jeremy Weate were awarded first place in the Shinkenchiku Residential Design Competition of 1996 for a series of time-lapse photographs with multiple exposures that displays a "phase space"an environment that responds directly to its users. Credits Richard Scott, Kirsten Whittle, and Jeremy Weate, The Japan Architect (Winter 1996 IV), p. 227. 


\section{Notes}

\section{Acknowledgments}

The research for this article received funding from the European Union's Horizon 2020 research and innovation program under the Marie Skłodowska-Curie grant agreement 797002, "Architecture as a Cross-Cultural Exchange: The Shinkenchiku Residential Design Competition, 1965-2017."

01. The publication of an article on the Sogo Department Store in Osaka (1935) designed by Togo Murano caused a dispute within the office of the Shinkenchiku publishing house, which resulted in the dismissal of the editorial staff. After this incident, the new editor shied away from criticism, with the result that Shinkenchiku magazine became fairly neutral in its observations. The Shinkenchiku Residential Design Competition would thus really stand out from the rest of the magazine. Author's interview with the editor of Shinkenchiku, Takeshi Ishido, Tokyo, November 28, 2018.

02. Although the Shinkenchiku competition has been generous in its distribution of prizes, awarding at times as many as thirty prizes and honorable mentions in one edition of the competition, all of which were published in the pages of The Japan Architect and Shinkenchiku, the discussion would even be richer if we could include an archive of entries that were not awarded prizes and as such were never acknowledged as making a contribution to the competition-related debate. To address the issue of an archive of such "lost" entries, this author is preparing an exhibition based on a call for such entries. A website accompanying the exhibition will collect the "lost" entries in an online archive.

03. DANIELL, Thomas, "The Fugitive," in Toyo Ito (ed.), Tarzans in the Media Forest, vol. 8.: Architecture Words, Architectural Association, London, 2011, p. 5.

04. ITO, Toyo, competition announcement, "The Shinkenchiku Residential Design Competition 1988," p. 6.

05. Ibid.

06. LEUPEN, Bernard, and KOOLHAAS, Rem, Hoe Modern is de Nederlandse Architectuur?, 010 Publishers, Rotterdam, 1990.
07. FUJIKI, Yosuke, "Winners in the 1992 Shinkenchiku Residential Design Competition," The Japan Architect, Spring 1993, pp. 8-11.

08. KOOLHAAS, Rem, "About the Results," The Japan Architect, Spring 1993, p. 7.

09. Ibid.

10. IMAFUJI, Akira, "Winners in the 1992 Shinkenchiku Residential Design Competition," The Japan Architect, Spring 1993, pp. 24-25.

11. WOODS, Kevin, and SHERIDAN, Charlotte, "Winners in the 1992 Shinkenchiku Residential Design Competition," The Japan Architect, Spring 1993, pp. 30-31.

12. MACKENZIE, Joanne, and DAVIES, Garth, "Winners in the 1992 Shinkenchiku Residential Design Competition," The Japan Architect, Spring 1993, pp. 40-41

13. KOOLHAAS, Rem, "About the Results," The Japan Architect, Spring 1993, p. 7.

14. SEJIMA, Kazuyo, "Competition Announcement: The Shinkenchiku Residential Design Competition1996," The Japan Architect II, Summer 1996, p. 3.

15. SEJIMA, Kazuyo, "Judge's Comments," The Japan Architect IV, Winter 1996, p. 224.

16. Author's interview with Krešimir Rogina, June 6, 2020.

\section{Ibid.}

18. Author's interview with Pornchai Boonsom, June 20, 2020. 


\section{Bibliography}

- DANIEL, Thomas, “The Fugitive,” in Toyo Ito, Tarzans in the Media Forest, vol. 8. Architecture Words, Architectural Association, London, 2011.

- GARGIANI, Roberto, and KOOLHAAS, Rem, Rem Koolhaas/OMA: The Construction of Merveilles, EPFL Press, Lausanne, 2019.

- ITO, Toyo, Competition Announcement, "The Shinkenchiku Residential Design Competition 1988," The Japan Architect, March 1988, pp. 6-7.

- ITO, Toyo, "Comfort in the Metropolis: In the Narrow Defile Between Reality and Fiction," The Japan Architect, March 1989 , 383 , pp. 30-33.

- KOOLHAAS, Rem, "The Shinkenchiku Residential Design Competition 1992," The Japan Architect Il, 1992, pp. 2-3.

- KOOLHAAS, Rem, "About the Results," The Japan Architect I, 1993, Annual, pp. 6-7.

-KOOLHAAS, Rem, "Why I Wrote Delirious New York and Other Textual Strategies," Architecture New York, May/June 1993, Writing in Architecture, pp. 42-43.

- LEUPEN Bernard, and KOOLHAAS, Rem, Hoe Modern is de Nederlandse Architectuur?, 010 Publisher, Rotterdam, 1990.

- NUIJSINK, Cathelijne, Interview with Azby Brown, September 19, 2019.

- NUIJSINK, Cathelijne, Interview with JeanPhilippe Lanoire, July 9, 2020.

- NUIJSINK, Cathelijne, Interview with Jos Roodbol, April 25, 2019.

- NUIJSINK, Cathelijne, Interview with Jurgen Mayer, June 19, 2020.

- NUIJSINK, Cathelijne, Interview with Kirsten Wittle, June 15, 2020.

- NUIJSINK, Cathelijne, Interview with Krešimir Rogina, June 6, 2020.

- NUIJSINK, Cathelijne, Interview with Mitsugo Okagawa, June 20, 2020.

- NUIJSINK, Cathelijne, Interview with Peter Wilson, July 7, 2019.
- NUIJSINK, Cathelijne, Interview with Toshikazu Ishida, July 26, 2019.

- NUIJSINK, Cathelijne, Interview with Yosuki Fujiki, June 24, 2020.

- NUIJSINK, Cathelijne, Interview with Pornchai Boonsom, June 2O, 2020.

- SEJIMA, Kazuyo, "The Possibilities of Non-Movement ...," The Japan Architect II, Summer 1996, pp. 2-3.

-SEJIMA, Kazuyo, “Judge's Comments," The Japan Architect IV, Winter 1996, pp. 224-25.
RA. Revista de Arquitectura Núm. 23 - 2021 P. 174-189 